\title{
Use of Panoramic Radiography to Detect Prevalence of Impacted Third Molar AmongChineseStudents In Faculty of Dentistry, University of Sumatera Utara
}

\author{
Cek Daramanja ${ }^{1}$, Loh Yuan Jing ${ }^{2}$ \\ *Department of Oral And Maxillofacial RadiologyFaculty of Dentistry University of Sumatera Utara \\ Jl. Alumni No. 2 Kampus USU Medan
}

\begin{abstract}
Impacted tooth is defined as normal eruption path of tooth that being blocked, normally by adjacent tooth or pathology tissue until its did not grow ideally on dental arch. Third molar is the latest eruption tooth in oral cavity, between 18-25 years old, This condition may causes third molar more frequently impacted compare to other tooth due to lack of space for eruption. This study aims to know the prevalence of impacted third molar on Chinese students seen from panoramic radiography in Faculty of Dentistry, University of Sumatera Utara (USU). This research was descriptive with sample of 50 Chinese students consisting of 14 males and 36 females that experiences impaction of third molar. Sample taking method used was purposive sampling. The research was conducted in Radiology Department, Faculty of Dentistry USU. The results of research showed the prevalence differences on maxilla and mandibular between men and women. In conclusion, the horizontal angulation in the mandible and vertical angulation in the maxilla were the most common angular position. Type $A$ in the mandible and type $B$ in the maxilla were the most common types of impaction's depth. Relationship between the position of the tooth to distal of second molar on mandible more cases on class II. This research showed prevalence impacted third molar on women were $75,78 \%$ and men were $24,22 \%$. Ratio between women to men was 3,1:1.
\end{abstract}

Keyword:Impacted third molar, Panoramic radiography, Chinese students

\section{Introduction}

Impacted tooth define as tooth that fail to erupt into dental arch during the period its suppose to erupt. ${ }^{1}$ Etiology of impacted tooth divide into factor local and factor systemic. ${ }^{2}$ Factor local such as abnormal position, pressure from adjacent tooth, increasing density of bone around the teeth and lack of space on dental arch. Factor systemic divide into prenatal cause, postnatal cause, abnormal endocrine system and malnutrition, ${ }^{3}$ Classification Pell and Gregory was used to determine depth, relationship of third molar to ramus mandibular and classification George Winter was used to determine angulation of tooth position. ${ }^{4,5}$

Radiography examination often use as supporting examination to evaluate cases of impacted third molar. ${ }^{6}$ Oral shape and other part of bodyare influence by age, gender, ethnic and culture. Grow of oral shape, jaw and tooth size are difference on every ethnics. This also applied to position of impacted tooth. ${ }^{7}$

This research aims to obtain prevalence of impacted third molaramong Chinese students in Faculty of Dentistry, University of Sumatera Utara and prevalence of impacted third molar based on gender.

\section{Materials and Methods}

Type of research was descriptive. Sample on this research consists of 50 Chinese students from Faculty of Dentistry, University of North Sumatera. All samples for this research must fulfill the inclusive and exclusive criteria. Inclusive criteria such as two generation Chinese and above, agreed and signed inform consent and consist of molar two on maxilla and mandibular. Exclusive criteria was fully erupted third molar.

Method to choosesample started with distribution of questioner paper and intra oral check-up. After that, collect back every questioner paper that has been filled up and screening process goes on at the same time. To those sampleswho are qualified, they are given informed consent to sign. Research procedure such as following steps:

a. Radiography panoramic machine was used in this research isInstrumentarium brand OS 200 D 1-4.

b. Measurement on inclination of impacted third molar by using George Winterclassification to evaluate position third molar to second molar on panoramic radiograph.

c. Measurement on depth of impacted third molar by using classification to evaluate higher point of third molar to second molar on panoramic radiograph.

d. Measurement on relationship impacted third molar to ramus mandibular according to Pell and Gregoryclassification. 
Maxillary and mandibular third molars are classified radiographically by angulation, depth and arch length or relationship to the anterior aspect of the ascending mandibular ramus. Pell and Gregory classification based on relationship of the impacted lower third molar to the ramus of the mandible and the second molar.

1) Class I: Sufficient space available between the anterior border of the ascending ramus and the distal side of the second molar for the eruption of the third molar.

2) Class II: The space available between the anterior border of the ramus and the distal side of the second molar is less than the mesio-distal width of the crown of the third molar.

3) Class III: The third molar is total embedded in the bone from the ascending ramus because of absolute lack of space

Classification of Pell and Gregory based on depth.

1) Level A: The highest position of the tooth is on a level with or above the occlusal line.

2) Level B: Highest position is below the occlusal plane, but above the cervical level of the second molar.

3) Level C: Highest position of the tooth is below the cervical level of the second molar.

Classification based on angulation according to the position of the impacted third molar to the long axis of the second molar. The George Winter classification is suggested:

1. Mesioangular

2. Distoangular

3. Horizontal

4. Vertical

Data analysis method was carried out by using manual and computerized program SPSS version 19.

Data obtained classified according to its variable and frequency distribution table.

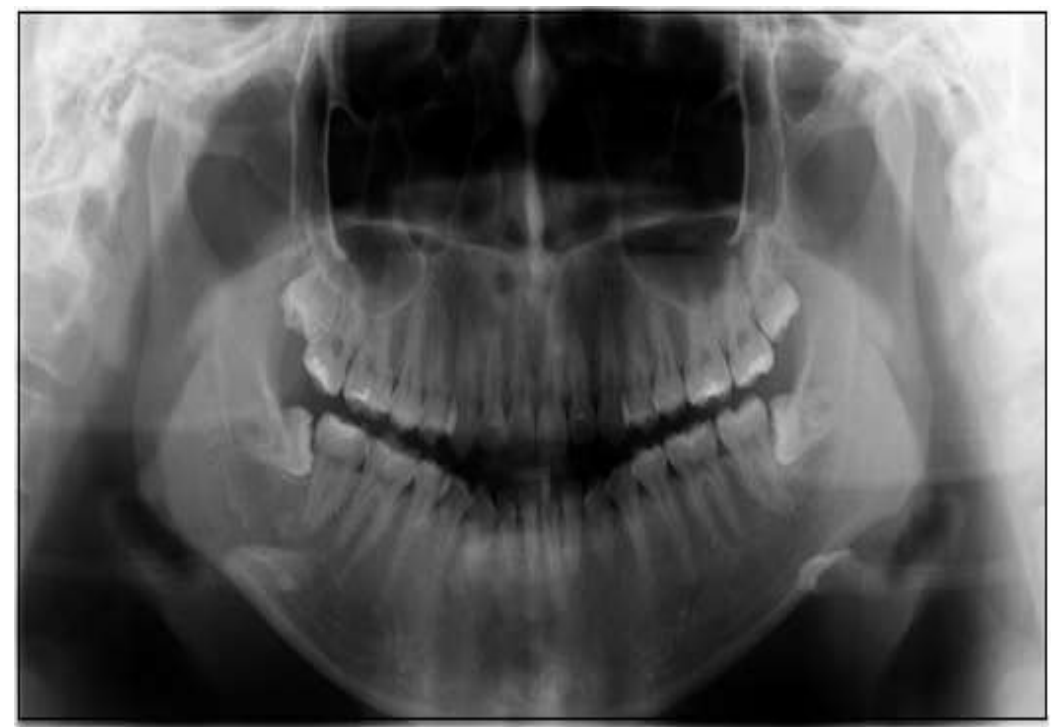

Picture 1. Impacted third molar on mandibular, horizontal position, class II

Relationshipto ramus and depth level B

\section{Result}

Result of research obtained from 50 Chinese students showed 128 tooth or $64 \%$ are impacted.(Tabel 1). Ratio of impacted third molar between women to men are $3,1: 1$ (Table 2).

Table 1. Percentageof impacted third molar based on element of tooth on Chinese students.

\begin{tabular}{|c|c|c|c|c|c|c|c|c|c|c|}
\hline & \multicolumn{3}{|c|}{18} & \multicolumn{2}{|c|}{28} & \multicolumn{3}{c|}{38} & \multicolumn{3}{|c|}{48} & \multicolumn{2}{c|}{ Total } \\
\cline { 2 - 12 } & $\mathrm{N}$ & $\%$ & $\mathrm{~N}$ & $\%$ & $\mathrm{~N}$ & $\%$ & $\mathrm{~N}$ & $\%$ & $\mathrm{~N}$ & $\%$ \\
\hline Normal & 9 & 18 & 11 & 22 & 4 & 8 & 3 & 6 & 27 & 13,5 \\
\hline Agenesis & 10 & 20 & 11 & 22 & 12 & 24 & 12 & 24 & 45 & 22,5 \\
\hline Impacted Tooth & 31 & 62 & 28 & 56 & 34 & 68 & 35 & 70 & 128 & 64,0 \\
\hline Total & 50 & 100 & 50 & 100 & 50 & 100 & 50 & 100 & 200 & 100 \\
\hline
\end{tabular}

Table2. Percentage of impacted third molar based on ratio between men and women.

\begin{tabular}{|c|c|c|c|c|c|c|c|c|c|c|c|}
\hline Element & \multicolumn{2}{|c|}{18} & 28 & \multicolumn{2}{|c|}{38} & \multicolumn{2}{|c|}{48} & \multicolumn{3}{|c|}{ Total } & \\
\hline Gender & $\mathrm{N}$ & $\%$ & $\mathrm{~N}$ & $\%$ & $\mathrm{~N}$ & $\%$ & $\mathrm{~N}$ & $\%$ & $\mathrm{~N}$ & $\%$ & Ratio \\
\hline Women & 26 & 20, & 22 & 1 & 25 & 19,5 & 24 & 1 & 97 & 75,7 & 3,1 \\
& & 31 & & 7, & & 3 & & 8, & & 8 & \\
& & & & 1 & & & & 7 & & & \\
\hline
\end{tabular}


Use Of Panoramic Radiography To Detect Prevalence Of Impacted Third Molar Amongchinesestuden..

\begin{tabular}{|c|c|c|c|c|c|c|c|c|c|c|c|}
\hline & & & & 9 & & & & 5 & & & \\
\hline Men & 5 & 3,9 & 6 & 4, & 9 & 7,03 & 11 & 8, & 31 & 24,2 & 1 \\
& & 1 & & 6 & & & & 5 & & 2 & \\
\hline Total & 31 & 24, & 28 & 2 & 34 & 26,5 & 35 & 2 & 128 & 100 & \\
& & 22 & & 1, & & 6 & & 7, & & & \\
& & & & 8 & & & & 3 & & & \\
\hline
\end{tabular}

Percentage of impacted third molar on maxilla based on inclination, the highest are vertical position, on the right is $67,7 \%$, and on the left is $53,5 \%$. Based on depth the the highest are level $\mathrm{B}$, on the right is $67,7 \%$ and on the left is $53,5 \%$ (Table 3 and Table 4)

Tabel 3.Percentage of third molaron right maxilla based on inclination

\begin{tabular}{|c|c|c|c|c|c|}
\hline \multicolumn{6}{|c|}{ Impacted Third Molar on Right Maxilla } \\
\hline \multicolumn{3}{|c|}{ Inclination } & \multicolumn{3}{|c|}{ Depth } \\
\hline Position & $\mathrm{N}$ & $\%$ & Level & $\mathrm{N}$ & $\%$ \\
\hline Mesioangular & 1 & $3,2 \%$ & $\mathrm{~A}$ & 1 & 3,2 \\
\hline Distoangular & 6 & 19,4 & $\mathrm{~B}$ & 21 & 67,7 \\
\hline Vertical & 21 & 67,7 & $\mathrm{C}$ & 9 & 29,1 \\
\hline Horizontal & 1 & 3,2 & & & \\
\hline Other & 2 & 6,5 & & & \\
\hline Total & 31 & 100 & Total & 31 & 100 \\
\hline
\end{tabular}

Table 4.Percentage of third molaron left maxilla based on inclination

\begin{tabular}{|c|c|c|c|c|c|}
\hline \multicolumn{6}{|c|}{ Impacted Third Molar on Left Maxilla } \\
\hline \multicolumn{3}{|c|}{ Inclination } & \multicolumn{3}{|l|}{ Depth } \\
\hline Position & $\mathrm{N}$ & $\%$ & Level & $\mathrm{N}$ & $\%$ \\
\hline Mesioangular & 3 & $\cdot 10,7$ & A & 1 & 3,5 \\
\hline Distoangular & 7 & 25,0 & $\mathrm{~B}$ & 15 & 53,5 \\
\hline Vertical & 15 & 53,5 & \multirow[t]{2}{*}{$\mathrm{C}$} & \multirow[t]{2}{*}{12} & \multirow[t]{2}{*}{43} \\
\hline Horizontal & 1 & 3,6 & & & \\
\hline Other & 2 & 7,2 & & & \\
\hline Total & 28 & 100 & Total & 28 & 100 \\
\hline
\end{tabular}

Percentage impacted third molar on mandibular based on inclination the highest is horizontal position, on the right is $48,6 \%$ and on the left is $38,2 \%$. Based on depth the highest is level A, on the right is $43 \%$ and on the left is $47 \%$. Based on relationship to ramus mandibular the highest is class II, on the right is $62,8 \%$ and on the left is 67,6\%. (Tabel 5 and Tabel 6).Prevalence impacted third molar more often happen in mandibular compare to maxilla(Table 7).

Table 5.Percentage of impacted third molar on right mandibular based on inclination, depth,relationship of ramus mandibular.

\begin{tabular}{|c|c|c|c|c|c|c|c|c|}
\hline \multicolumn{9}{|c|}{ Impacted Third Molar on Right Mandibular } \\
\hline \multicolumn{3}{|c|}{ Inclination } & \multicolumn{3}{|c|}{ Depth } & \multicolumn{3}{|c|}{ Relationship of Ramus } \\
\hline Position & $\mathrm{N}$ & $\%$ & Level & $\mathrm{N}$ & $\%$ & Class & $\mathrm{N}$ & $\%$ \\
\hline Mesioangular & 7 & 20.0 & A & 15 & 43.0 & $\mathrm{I}$ & 2 & 5.7 \\
\hline Distoangular & 0 & 0 & $\mathrm{~B}$ & 12 & 34.2 & II & 22 & 62.8 \\
\hline Vertical & 10 & 28.6 & $\mathrm{C}$ & 8 & 22.8 & III & 11 & 31.5 \\
\hline Horizontal & 17 & 48.6 & & & & & & \\
\hline Other & 1 & 2.8 & & & & & & \\
\hline Total & 35 & 100 & Total & 35 & 100 & Total & 35 & 100 \\
\hline
\end{tabular}

Tabel 6.Percentage of impacted third molar on left mandibular based on inclination, depth, relationship of ramus mandibular.

\begin{tabular}{|c|c|c|c|c|c|c|c|c|}
\hline \multicolumn{9}{|c|}{ Impacted Third Molar on Left Mandibular } \\
\hline \multicolumn{3}{|c|}{ Inclination } & \multicolumn{3}{|c|}{ Depth } & \multicolumn{3}{|c|}{ Relationship of Ramus } \\
\hline Posisi & $\mathrm{N}$ & $\%$ & Level & $\mathrm{N}$ & $\%$ & Class & $\mathrm{N}$ & $\%$ \\
\hline Mesioangular & 8 & 23.5 & $\mathrm{~A}$ & 16 & 47.0 & $\mathrm{I}$ & 2 & 5.8 \\
\hline Distoangular & 0 & 0 & B & 14 & 41.0 & II & 23 & 67.6 \\
\hline Vertical & 11 & 32.5 & $\mathrm{C}$ & \multirow[t]{3}{*}{4} & \multirow[t]{3}{*}{12.0} & \multirow[t]{3}{*}{ III } & \multirow[t]{3}{*}{9} & \multirow[t]{3}{*}{26.6} \\
\hline Horizontal & 13 & 38.2 & & & & & & \\
\hline Other & 2 & 5.8 & & & & & & \\
\hline Total & 34 & 100 & Total & 34 & 100 & Total & 34 & 100 \\
\hline
\end{tabular}


Tabel 7. Percentage of prevalence of impacted on upper and lower jaws..

\begin{tabular}{|c|c|c|}
\hline Jaw & N & Impacted Third Molar \\
\hline & 31 & 24,22 \\
\hline Right Maxilla & 28 & 21,88 \\
\hline Left Maxilla & 35 & 27,34 \\
\hline Right Mandibular & 34 & 26,56 \\
\hline Left Mandibular & 128 & 100 \\
\hline Total & & \\
\hline
\end{tabular}

\section{Discussion}

Prevalence impacted third molar on Chinese students age between 18-25 years old from year 20092014 was $64 \%$. This value almost similar to a few researches done by other researcher in other country on different ethnics was between 20-70\%. This research using Chinese students as sample, Chinese are categorized under Mongoloid race. Whereby this is difference when compare to Kannepaddy, et al. (2013) research due to on his research, his samples included 3 difference races such as Indian, Malay and Chinese. Result of his research shown prevalence of impacted third molar on Chinese is $38,6 \%$, Malay is $30,7 \%$ and Indian is $30,7 \%$. This differences because of the variety in diet and living habits. Besides that, other elements that cause higher of prevalence due to Chinese jaw shape are tapered with wider inter-molar which this circumstances cause lack of space for third molar to erupt.

Prevalence impacted third molar on women were $75,7 \%$ and men were $24,3 \%$, ratio between women to men were $3,1: 1$. This research showed impacted third more happened to women more higher compare to men. This result was support by other such as Chu, et al.(2003) his research obtained result prevalence of impacted third occurred more on women compare to men, ratio between women to men were $1,2: 1{ }^{8}$ Research of Obimakinde (2012) also report that ratio between women to men were 1,15:1. ${ }^{9}$ Research of Mazola, et al. (2005) obtained result of ratio between women to men were 1,8:1. ${ }^{10}$ This situation occur simply because growing process of women jaw stop when third molar starting to erupt, whereby on men, their jaw still undergoes growing process while third molar is still erupting. Thus this allow more available space for eruption of third molar in men.

On this research, the highest prevalence of position impacted third molar on maxilla was vertical whereby the percentage was $61,02 \%$.. This result was supported by Byatti el al. (2012), his result shown highest occurrence on maxilla was vertical and percentage was $72,17 \% .{ }^{11}$ On this research, the highest prevalence of position impacted third molar on mandibular was horizontal, and the percentage was 43,48\%. This result supported by $\mathrm{Chu}$, et al(2003), his research shows the highest prevalence on mandibular was horizontal with the percentage of $47,5 \%$, but this is difference compare to Tahrir et al. (2010), on his research obtained the result of highest prevalence position was mesioangular with the percentage of $57 \% .^{8,12}$

On this research the highest prevalence depth level of impacted third molar on maxilla was level B with the percentage of $60,6 \%$ and on mandibular was level A with the percentage of $45 \%$. This result similar to Naziret.al (2014) research where he obtained depth level highest occur on mandibular was level A with the percentage of $62,8 \% .{ }^{13}$ Kanneppady et al. (2013) shown the similar result, on his research highest prevalence on mandibular was level A with the percentage of $41,9 \% .^{7}$ Based on relationship third molar to ramus mandibular more often occur was class II with the percentage of 67,9\%, this result is supported by Nazir et al (2014), class II was the highest occurrence with the percentage $53,5 \%$.

Impacted third molar more frequently occur on right mandibular with the percentage of $27,34 \%$ and on left mandibular with the percentage of $26,26 \%$. By the way on the right maxilla was $24,22 \%$ and on the left maxilla was 21,88\%. This result is supported by Arsalan et al. (2013) and Mehdizadeh et al.(2014) whereby they found frequency impacted third molar happen more in mandibular compare to maxilla. But that is no significant differences of prevalence impacted third molar on maxilla to mandibular whether on the left or the right. ${ }^{14,15}$

Third molar with the highest chances to become impacted may link to minimize of jaw eruption due to changes in diet, habits and genetic. Changes in diet and living habits affect the functional stimulus that is the primary stimulus for jaw grows and simultaneously cause jaw unable achieve optimal grow. This also narrows the space for tooth eruption. As the final tooth to erupt, third molar stands the highest chances to be impacted compare to others.

Conclusion of this research was prevalence impacted third molar on Chinese students by using panoramic radiography based on inclination on maxilla was vertical with the percentage of 59,33\%, on mandibular the highest was horizontal with the percentage of $41,89 \%$. Based on depth on maxilla the highest was level B with the percentage of $60,6 \%$. On mandibular the highest was level A with the percentage of $45 \%$. Based on relationship to ramus mandibular the highest was class II with the percentage of $67 \%$. Prevalence impacted third molar based on gender, impacted third molar happened in women were greater than in men, with the ratio of $3,1: 1$. 


\section{References}

[1]. Peterson L J, Ellis E, Hupp J R, Tucker M R. Contemporary oral and maxillofacial surgery. 4th ed. The C.V.Mosby Company St. Louis, 2003;140-8.

[2]. Chanda MH. Zahbia ZN. Pengaruh bentuk gigi geligi terhadap terjadinya impaksi gigi molar ketiga rahang bawah. Dentofasial J Kedokteran Gigi 2007; 6(2): 65-6

[3]. Balaji SM. Oral and maxillofacial surgery. Delhi: Elsevier; 2009: 233-4

[4]. Neelima Anil Malik. Oral and maxillofacial surgery. ${ }^{\text {rd }}$ ed. Jayoee Brothers Medical Publishers. 2012; 147-9.

[5]. Fragishor DF. Oral surgery. Germany: Springer. 2007; 125-7.

[6]. Ardakani FE, Behniafar B, Booshehri MZ. Evaluation of the distortion rate of panoramic and periapical radiograph in eruted third molar inclination. Iranian J of Radiology. 2011;8(1): 15-21.

[7]. Kanneppady,Balamanikandasrinivasan, Sakri S B. A comparative study on radiographic analysis of impacted third molars among three ethnic groups of patients attending AIMST Dental Institute, Malaysia. Dent Res J (Isfahan) 2013; 10 (3): 353-8.

[8]. Chu FCS, TKL Li, VKB Lui, PRH Newsome, RLK Chow, Lk Cheung. Prevalence of impacted teeth and asscociated pathologies, A radiographic study of Hongkong Med $\mathbf{J} 2003$.

[9]. Obikimakinde OS. Impacted mandibular third molar surgery; an overview Tsitsogianis H. Berlin: Springer; 2001, 126-7.

[10]. Marzola C, Comparin E, Filho JLT. Third molars classification prevalence in the cities of cunhapora, maravilha and palmitos in the northwest of state in brazil. http://www.artiradentes.com.br/revista/2007/textos/3RevistaATOPrevalence_Third_Molars_Position2007.pdf(14 Jan 2015)

[11]. Byahatti S, Ingafou. Prevalence of eruption of third molars in Libyan students. Dent Research J(Isfahan), 2012; 9(2): 152-3.

[12]. Tahrir N, Suheir W, Afrah A. The evaluation of impacted third molars using panoramic

[13]. radiograph. J of Research andPractise in Dentistry 2010; 26-33.

[14]. Asif N, Muhammad U, Shahid A. Assessment of different of impacted mandibular third molars and their associated pathologies. Jof Advanced Medical and Dental Sciences Research 2014; 14-21.

[15]. Mohammad M, Sina H, Maryam S, Ali B, Rashid S. Radiograhic evaluation of impacted third molar and their complications in a group of Iranian population. Jof Research and Practise in Dentistry, 2014;1-11.

[16]. Arsalam W, Farrukh I, Syed A, Azka M, Ayesha K, Fatima K. Prevalence of impacted mandibular and maxillary third molars; a radiographic study in patients reporting Madina Teaching Hospital: Faisalabad; 2013; 22-31. 